\title{
Regulation of Serotonin Release in the Lateral Septum and Striatum by Corticotropin-Releasing Factor
}

\author{
Michelle L. Price ${ }^{1}$ and Irwin Lucki ${ }^{1,2}$ \\ 1David Mahoney Institute of Neurological Sciences and '2Departments of Psychiatry and Pharmacology, University of \\ Pennsylvania, Philadelphia, Pennsylvania 19104
}

The serotonergic dorsal raphé nucleus (DRN) is innervated by corticotropin-releasing factor (CRF)-immunoreactive fibers and contains CRF receptor-binding sites, suggesting that endogenous CRF regulates this system. The present study examined the possibility that $\mathrm{CRF}$ in the DRN regulates the release of serotonin (5-HT) in forebrain terminal regions. Intracerebroventricular administration of CRF produced a bimodal effect on extracellular levels of $5-\mathrm{HT}$ in the lateral septum. Doses of 0.3 and $1.0 \mu \mathrm{g}$ decreased extracellular 5 -HT levels, whereas both a higher $(3.0 \mu \mathrm{g})$ and a lower $(0.1 \mu \mathrm{g})$ dose had no effect. The reduction of extracellular $5-\mathrm{HT}$ in the lateral septum by CRF $(0.3$ $\mu$ g, i.c.v.) was blocked by pretreatment with the CRF receptor antagonist D-PheCRF ${ }_{12-41}$ (3.0 $\mu$ g, i.c.v.). Direct administration

Corticotropin-releasing factor (CRF) was initially isolated as the hypothalamic factor responsible for stimulating the release of adrenocorticotropic hormone from the anterior pituitary in response to stress (Vale et al., 1981). Anatomical studies have identified CRF-containing cell body groups, CRF-immunoreactive fibers, CRF receptors, and CRF receptor mRNA expression in diverse brain regions that are not directly involved with endocrine aspects of stress responses (Cummings et al., 1983; Swanson et al., 1983; Sakanaka et al., 1987) or its pituitary actions (DeSouza, 1987; Potter et al., 1994; Chalmers et al., 1995; Primus et al., 1997). The distribution of CRF fibers in neurovascular and subependymal fiber plexuses suggests a role in chemosensory functions (Ruggiero et al., 1999). CRF has also been suggested to act as a brain neurotransmitter that mediates the autonomic and behavioral components of stress responses (Dunn and Berridge, 1990; Owens and Nemeroff, 1991; Valentino et al., 1993). Intraventricular and intracerebral administration of CRF has been shown to affect several extrahypothalamic neurotransmitter systems (Dunn and Berridge, 1990), such as dopamine and norepinephrine (Matsuzaki et al., 1989; Butler et al., 1990; Lavicky and Dunn, 1993). CRF administered directly into the noradrenergic nucleus locus coeruleus (LC) increases neuronal activity (Valentino et al., 1983; Curtis et al., 1997; Page and Abercrombie, 1999), and LC activation evoked by certain stimuli is prevented by

\footnotetext{
Received Aug. 8, 2000; revised Dec. 6, 2000; accepted Jan. 11, 2001.

This research was supported by National Institute of Mental Health Grant MH 58250 and by National Research Service Award MH 12115 to M.L.P. We thank Dr. Rita J. Valentino for valuable discussions related to this manuscript and Dr. Jean Rivier for supplying different forms of CRF and D-PheCRF ${ }_{12-41}$.

Correspondence should be addressed Dr. Irwin Lucki, Department of Psychiatry, University of Pennsylvania, Room 538A Clinical Research Building, 415 Curie Boulevard, Philadelphia, PA 19104-6140. E-mail: lucki@pharm.med.upenn.edu. Copyright (C) 2001 Society for Neuroscience $\quad 0270-6474 / 01 / 212833-09 \$ 15.00 / 0$
}

of CRF (30 ng) into the DRN reduced extracellular 5-HT levels in the lateral septum and the striatum. Furthermore, injection of $\mathrm{D}^{-}$PheCRF $_{12-41}(10 \mathrm{ng})$ into the DRN before ventricular administration of CRF $(0.3 \mu \mathrm{g}$, i.c.v.) blocked the decrease in extracellular $5-\mathrm{HT}$ in both the lateral septum and striatum. Taken together, these data support the hypothesis that CRF may modulate 5-HT release in terminal regions via its effects at the level of the DRN. This modulation supports a potential interaction between CRF and 5-HT in stress-related psychiatric disorders in which both systems have been implicated.

Key words: corticotropin-releasing hormone; serotonin; dorsal raphé nucleus; microdialysis; lateral septum; striatum

intracoerulear administration of CRF receptor antagonists (Valentino et al., 1991; Curtis et al., 1994; Lechner et al., 1997).

The serotonin (5-HT) neurotransmitter system is also affected by CRF. The dorsal raphé nucleus (DRN), a major source of 5-HT cell bodies projecting to forebrain areas, contains CRFimmunoreactive fibers (Swanson et al., 1983; Sakanaka et al., 1987; Kirby et al., 2000) that are organized topographically according to the rostrocaudal level of the DRN (Kirby et al., 2000). Additionally, mRNAs for two CRF receptor subtypes (CRF-R1 and CRF-R2) and CRF receptor-binding sites are present in the DRN (DeSouza, 1987; Chalmers et al., 1995). Recent electrophysiology studies demonstrated that relatively low doses of CRF, administered intracerebroventricularly or intra-raphé, produced predominantly inhibitory effects on the discharge rates of DRN neurons that could be attenuated by CRF receptor antagonists (Price et al., 1998; Kirby et al., 2000). In accord, intracerebroventricular administration of CRF was shown to reduce extracellular levels of 5-HT in the striatum using in vivo microdialysis (Price et al., 1998).

The present study demonstrated an inhibitory regulation of extracellular 5-HT levels by intracerebroventricular CRF in two terminal regions innervated by the DRN, the lateral septum, a region that has been implicated in affective disorders, and the striatum, using in vivo microdialysis. The DRN was identified as the site of action for these inhibitory effects because local infusions of CRF made directly into the DRN reproduced the effects of intracerebroventricular CRF and because intra-raphé administration of the CRF receptor antagonist D-PheCRF $\mathrm{CR}_{12-41}$ blocked the effects of CRF administered intracerebroventricularly. Taken together, the results of these studies provide evidence of neuromodulatory effects of CRF within the DRN that may be responsible for the regulation of 5-HT release by stress. 


\section{MATERIALS AND METHODS}

Subjects. Adult male Sprague Dawley rats (250-300 gm; Charles River Laboratories, Wilmington, MA) were initially housed two per cage on a $12 \mathrm{hr}$ light/dark schedule in a temperature-controlled $\left(22^{\circ} \mathrm{C}\right)$ colony room. Rats were fed standard rat chow and water ad libitum. The care and use of animals were performed in accordance with the National Institutes of Health Guide for the Care and Use of Laboratory Animals.

In vivo microdialysis protocols. Guide cannulae were implanted in subjects that were anesthetized with sodium pentobarbital $(40 \mathrm{mg} / \mathrm{kg}$, i.p.) using a stereotaxic instrument (David Kopf, Tujunga, CA) with the nose bar set at $-3.5 \mathrm{~mm}$. Holes were drilled for three skull screws, a 20 gauge guide cannula for a microdialysis probe, and 22 gauge guide cannulae for intracerebroventricular or intra-raphé infusions. A single microdialysis guide cannula was implanted at one of the following coordinates: in the striatum, $-0.3 \mathrm{~mm}$ anteroposterior, $3.5 \mathrm{~mm}$ mediolateral, and $3.2 \mathrm{~mm}$ ventral to the brain surface; and in the lateral septum, +0.7 $\mathrm{mm}$ anteroposterior, $0.8 \mathrm{~mm}$ mediolateral, and $4.0 \mathrm{~mm}$ ventral to the brain surface. Infusion guide cannulae were implanted at the following coordinates as required: in the lateral ventricle, $-1.0 \mathrm{~mm}$ anteroposterior, $1.3 \mathrm{~mm}$ mediolateral, and $4.5 \mathrm{~mm}$ ventral to the skull; and in the dorsal raphé, $-7.8 \mathrm{~mm}$ anteroposterior, $2.8 \mathrm{~mm}$ mediolateral, and 5.3 $\mathrm{mm}$ ventral to the brain surface at a $25^{\circ}$ angle (Paxinos and Watson, 1986). A schematic of the sites is shown in Kirby et al. (1995). The cannulae were affixed to the skull with cranioplastic cement, and the incision was closed with wound clips.

After surgery, subjects were individually housed and allowed 1 week to recover. Rats were handled a minimum of four times before microdialysis experiments to minimize the nonspecific effects of handling during experimentation. On the day before the experiment, rats were placed into a clear polycarbonate cylindrical microdialysis apparatus $(37.5 \mathrm{~cm}$ high) with a counterbalance arm attached to a liquid swivel and spring tether to allow free movement (Instech Laboratories, Plymouth Meeting, PA). A dialysis probe was inserted into the guide cannula aimed at either the lateral septum or striatum. Custom concentric-style dialysis probes were constructed as described previously (Kirby et al., 1997; Price et al., 1998) and perfused continuously during the experiment with filtered artificial CSF (ACSF; $147 \mathrm{~mm} \mathrm{NaCl}, 1.7 \mathrm{~mm} \mathrm{CaCl}_{2}, 0.9 \mathrm{~mm} \mathrm{MgCl}$, and $4 \mathrm{~mm} \mathrm{KCl}, \mathrm{pH}$ 6.3-6.5) at a rate of $0.8 \mu \mathrm{l} / \mathrm{min}$ using an Instech syringe pump (Instech Laboratories) through tubing inserted through the liquid swivel. Starting the following day (17-20 hr after probe insertion) dialysate samples were collected at $20 \mathrm{~min}$ intervals for $2 \mathrm{hr}$ before ventricular or intra-raphé injections. Animals received intracerebroventricular injections of ovine CRF (oCRF; 0.1-3.0 $\mu \mathrm{g}$ in 3.0 $\mu \mathrm{l}$ of ACSF), rat/human CRF (r/hCRF; $0.3-1.0 \mu \mathrm{g}$ in $3.0 \mu \mathrm{l}$ of ACSF), D-PheCRF ${ }_{12-41}(3.0 \mu \mathrm{g}$ in $3.0 \mu \mathrm{l}$ of ACSF), or ACSF (3.0 $\mu \mathrm{l})$ over a $30 \mathrm{sec}$ period. Animals received intra-raphé injections of oCRF (3.0-30.0 $\mathrm{ng}$ in $100 \mathrm{nl}$ of ACSF), D-PheCRF ${ }_{12-41}$ (10 ng in $100 \mathrm{nl}$ of ACSF), or ACSF (100 nl) over a $1 \mathrm{~min}$ period using tubing attached to a Hamilton syringe and an Instech syringe pump. Samples were collected at $10 \mathrm{~min}$ intervals for $40-70 \mathrm{~min}$ after injections and then at $20 \mathrm{~min}$ intervals for the remainder of the experiment. Samples were collected into polypropylene microcentrif uge vials (Fisher Scientific, Pittsburgh, PA) and stored at $-80^{\circ} \mathrm{C}$ until analysis. At the end of the experiment, $3 \mu \mathrm{l}$ of pontamine sky blue was injected through the intracerebroventricular cannula, and $200 \mathrm{nl}$ of pontamine sky blue was inf used into the DRN. Animals were killed with a lethal dose of pentobarbital $(100 \mathrm{mg} / \mathrm{kg}$, i.p. $)$, and the brains were removed, frozen in isopentane, and stored at $-20^{\circ} \mathrm{C}$ until sectioned.

Initial experiments examined the ability of intracerebroventricular administration of various doses of oCRF $(0.1-3.0 \mu \mathrm{g})$ to alter extracellular 5-HT levels in the lateral septum. The effects were compared with those measured in the striatum that were published previously (Price et al., 1998). To confirm that the effects of CRF were caused by actions at CRF receptors, intracerebroventricular administration of the CRF receptor antagonist D-PheCRF ${ }_{12-41}$ administered $30 \mathrm{~min}$ before intracerebroventricular oCRF was used to block the effects of intracerebroventricular oCRF on lateral septum 5-HT levels. To identify the site of action of CRF, separate groups of animals received intra-raphé infusions of oCRF, and alterations in extracellular 5-HT were measured in either the lateral septum or striatum. In addition, the ability of intra-raphé D-PheCRF ${ }_{12-41}$ or ACSF, infused 9 min before intracerebroventricular oCRF, to attenuate the oCRF-induced changes in 5-HT levels in the lateral septum or the striatum was assessed. Finally, to obtain information on the activity of different forms of CRF, the effects of intracerebroventricular oCRF were compared with the effects of intracerebroven- tricular $\mathrm{r} / \mathrm{hCRF}$ on extracellular 5-HT levels in the lateral septum and the striatum.

Analysis of dialysate samples. Dialysates were automatically injected into a Bioanalytical Systems 460 HPLC equipped with a reverse-phase $1 \times 100 \mathrm{~mm}$ ODS $3 \mu \mathrm{m}$ microbore column (C18; Bioanalytical Systems, West Lafayette, IN) by a CMA/200 Refrigerated Microsampler (CMA, Stockholm, Sweden) set to a $6.5 \mu \mathrm{l}$ injection volume. The HPLC mobile phase $\left(0.67 \mathrm{~mm}\right.$ EDTA, $0.43 \mathrm{~mm}$ sodium octyl sulfate, $32 \mathrm{~mm} \mathrm{NaH} \mathrm{PO}_{4}$, and $11-13 \%$ acetonitrile, $\mathrm{pH} 3.7-4.0)$ was pumped through the column at a flow rate of $100 \mu \mathrm{l} / \mathrm{min}$ (Kreiss et al., 1993). The amount of 5-HT in each dialysate sample was quantified from the respective peak heights using a linear regression analysis of the peak heights obtained from a series of reference standards. The detection limit, defined as the sample amount producing a peak height twice the height of background noise, was typically $0.5 \mathrm{fmol}$. This sensitivity is more than sufficient to measure baseline levels of 5-HT without the need to add a 5-HT uptake inhibitor to the perfusion medium.

Histological analysis. Brains were sectioned with a refrigerated cryostat and mounted on charged slides (Fisher Scientific). Sections were stained with neutral red and coverslipped for visualization of pontamine sky blue in the ventricular system and/or the DRN. The dialysis probe tract was also localized. Only rats with accurate placement of the infusion cannulae and dialysis probe membrane in the targeted structures were used in data analysis. There were no signs of toxicity in the region of the DRN after infusion of CRF or D-PheCRF ${ }_{12-41}$

Data analysis. Baseline values for 5-HT were corrected for individual probe recoveries. Probe recovery in vitro was measured with a standard solution of ACSF containing 5-HT (10 nM) at room temperature. The average recovery rate for 5 -HT was $22 \pm 0.3 \%$. Baseline levels were calculated for each rat by averaging six samples collected before treatment. Animals with a mean baseline level $<1$ fmol were excluded because a reduction $>50 \%$ could not be detected. The 5 -HT content of individual dialysate samples was expressed as a percentage of the mean of baseline samples. Mean baseline 5-HT levels were compared between groups by one-way ANOVA. The overall effect of treatment on 5-HT levels was assessed by two-way ANOVA. Comparisons between vehicle controls and CRF- or D-PheCRF ${ }_{12-41}$-treated animals were made using ANOVA followed by Fisher's test. The values at individual time points were compared with baseline values using a priori Fisher's test. Summed effects of treatment over the course of an experiment were measured by determining the area under the curve (AUC). AUC values were compared using a one-way ANOVA followed by Fisher's test for comparisons between control and experimental groups.

Drugs. Ovine CRF, rat/human CRF, and D-PheCRF ${ }_{12-41}$ were generously supplied by Dr. Jean Rivier of the Clayton Foundation Laboratories for Peptide Biology (The Salk Institute, La Jolla, CA). The peptides were dissolved in water to make a $1.0 \mathrm{mg} / \mathrm{ml}$ solution. Aliquots of this solution $(10 \mu \mathrm{l})$ were concentrated using a Savant Speed Vac concentrator. The resulting $10 \mu \mathrm{g}$ aliquots were stored at $-80^{\circ} \mathrm{C}$ and dissolved in ACSF on the day of the experiment.

\section{RESULTS \\ Basal extracellular 5-HT levels in the lateral septum and striatum}

The mean baseline dialysate level of 5-HT in the lateral septum across all treatment groups was $3.42 \pm 0.16 \mathrm{fmol} / 6.5 \mu \mathrm{l}$ sample ( $n=119$ rats). The mean baseline dialysate level of 5-HT in the striatum across all treatment groups was $3.42 \pm 0.36 \mathrm{fmol} / 6.5 \mu \mathrm{l}$ sample ( $n=37$ rats). Values for individual groups are provided in the figure captions. There were no significant differences in baseline levels between experimental groups for individual experiments.

\section{Effects of intracerebroventricular CRF on extracellular 5-HT levels}

Administration of CRF (0.1-3.0 $\mu$ g, i.c.v.) reduced extracellular levels of 5-HT in the lateral septum (Fig. 1), but the effects were dose dependent according to a bimodal dose-response curve. An overall two-way ANOVA indicated significant effects of dose $\left[F_{(4,26)}=4.12 ; p<0.05\right]$ and time $\left[F_{(11,286)}=4.30 ; p<0.01\right]$ but no significant interaction $\left[F_{(44,286)}=1.27\right.$; NS]. As shown in 

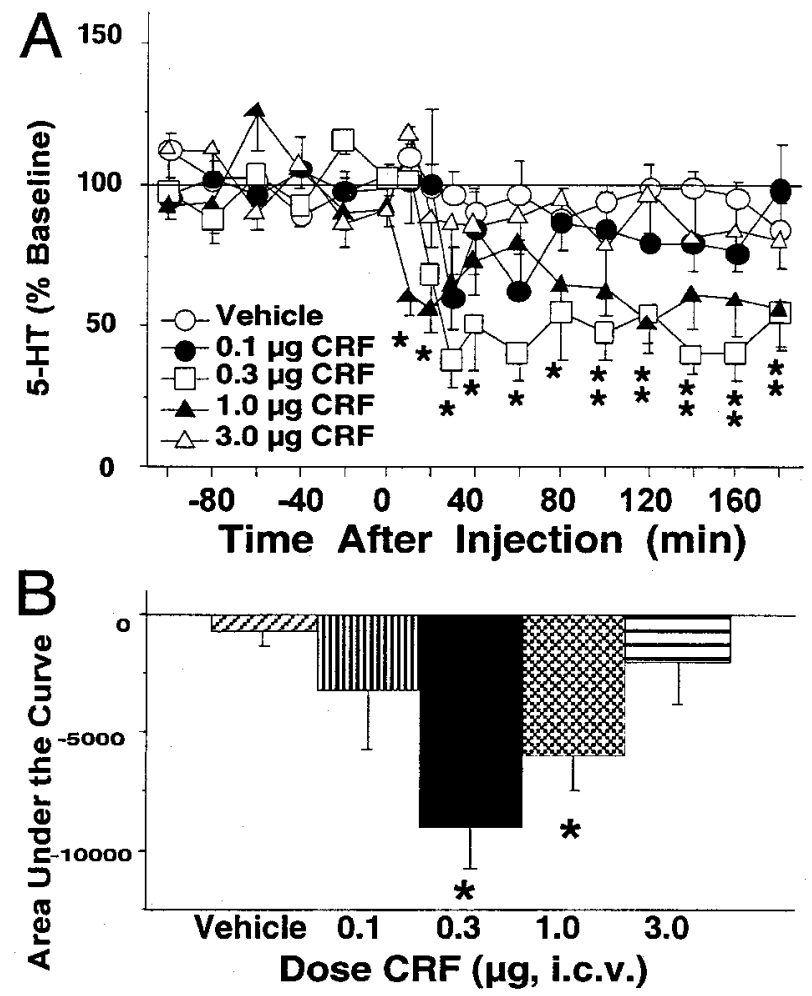

Figure 1. Effects of intracerebroventricular CRF on levels of 5-HT in the lateral septum. $A$, The $x$-axis indicates the time before and after the intracerebroventricular injection, which occurred at time $=0$. The $y$-axis indicates the extracellular 5-HT level per sample expressed as a percentage of the mean preinjection level. Shown are the effects of vehicle and CRF: vehicle (open circles; $n=7$; baseline 5 -HT $=4.48 \pm 0.22 \mathrm{fmol} / 6.5$ $\mu \mathrm{l}$ ), $0.1 \mu \mathrm{g}$ of CRF ( filled circles; $n=4$; baseline 5 -HT $=2.48 \pm 0.41$ $\mathrm{fmol} / 6.5 \mu \mathrm{l}$ ), $0.3 \mu \mathrm{g}$ of CRF (open squares; $n=6$; baseline 5 -HT $=3.76 \pm$ $0.88 \mathrm{fmol} / 6.5 \mu \mathrm{l}$ ), $1.0 \mu \mathrm{g}$ of CRF ( filled triangles; $n=7$; baseline $5-\mathrm{HT}=$ $3.58 \pm 1.02 \mathrm{fmol} / 6.5 \mu \mathrm{l}$ ), and $3.0 \mu \mathrm{g}$ of CRF (open triangles; $n=7$; baseline $5-\mathrm{HT}=5.86 \pm 1.07 \mathrm{fmol} / 6.5 \mu \mathrm{l})$. Error bars represent $1 \mathrm{SEM}$, and asterisks indicate time points that differ from the corresponding baseline $(p<0.05)$. Double asterisks were used to designate both the open square and the filled triangle. $B$, The vertical bars indicate the mean effect of vehicle or different doses of CRF on lateral septum 5-HT levels summed over time and effect and expressed as the area under the curve. Asterisks indicate the doses of CRF that differ from vehicle $(p<0.05)$.

Figure $1 A$, a significant decrease in lateral septum 5-HT was produced by 0.3 and $1.0 \mu \mathrm{g}$ of $\mathrm{CRF}$, as compared with vehicle ( $p<0.01$ for both). Extracellular levels of 5-HT were significantly reduced below baseline values from 30 to $180 \mathrm{~min}$ after the $0.3 \mu \mathrm{g}$ dose to a maximum of $62 \pm 10 \%$ below baseline values at $30 \mathrm{~min}$ after injection. After treatment with $1.0 \mu \mathrm{g}$ of CRF, lateral septum 5-HT levels were significantly reduced below baseline values from 10 to $20 \mathrm{~min}$ and again from 100 to $180 \mathrm{~min}$ after injection to a maximum of $49 \pm 11 \%$ below baseline values at 120 min after injection. Treatment with vehicle, $0.1 \mu \mathrm{g}$ of CRF, or 3.0 $\mu \mathrm{g}$ of CRF did not significantly alter 5-HT levels in the lateral septum. Figure $1 B$ compares the cumulative effects of the different doses of CRF on extracellular levels of 5-HT in the lateral septum using AUC values $\left[F_{(4,26)}=4.71 ; p<0.01\right]$. Values were significantly reduced in animals treated with 0.3 and $1.0 \mu \mathrm{g}$ of $\mathrm{CRF}$ as compared with vehicle $(p<0.01$ and $p<0.05$, respectively).

Pretreatment with D-PheCRF ${ }_{12-41}(3.0 \mu \mathrm{g}$, i.c.v.), a nonselective CRF receptor antagonist, significantly blocked the effects of CRF administration (0.3 $\mu$ g, i.c.v.) on extracellular levels of 5-HT

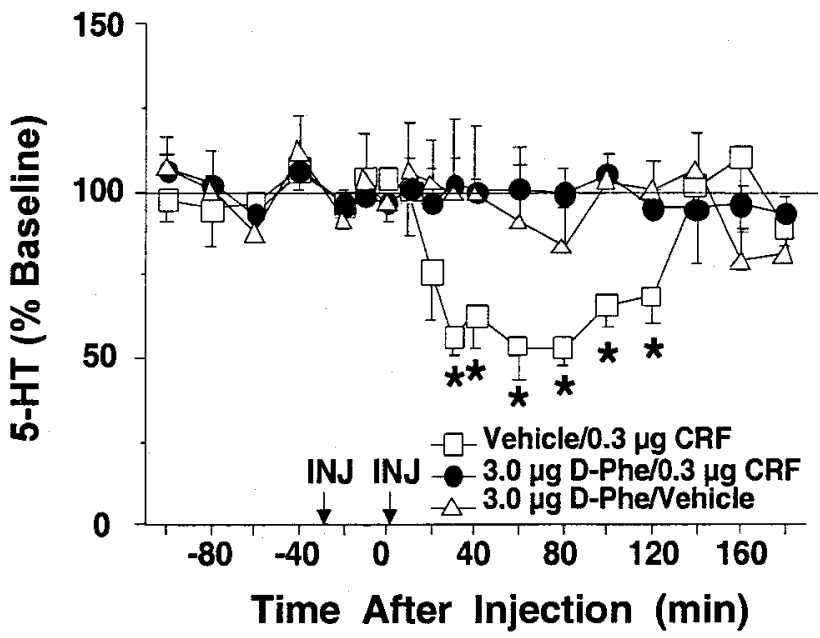

Figure 2. Effects of intracerebroventricular CRF after intracerebroventricular D-PheCRF ${ }_{12-41}$ on extracellular 5-HT levels in the lateral septum. The $x$-axis indicates the time before and after intracerebroventricular injections, which occurred at time $=-30 \mathrm{~min}$ (pretreatment) and time $=$ 0 min (treatment), respectively. The $y$-axis indicates the extracellular 5-HT level per sample expressed as a percentage of the mean preinjection level. The following effects are shown: vehicle pretreatment followed by CRF treatment (open squares; $n=7$; baseline $5-\mathrm{HT}=3.88 \pm 0.67$ fmol/6.5 $\mu \mathrm{l}$ ), D-PheCRF ${ }_{12-41}$ pretreatment followed by CRF treatment ( filled circles; $n=12$; baseline $5-\mathrm{HT}=2.42 \pm 0.46 \mathrm{fmol} / 6.5 \mu \mathrm{l}$ ), and D-PheCRF ${ }_{12-41}$ pretreatment followed by vehicle treatment (open triangles; $n=10$; baseline 5 -HT $=3.15 \pm 0.37 \mathrm{fmol} / 6.5 \mu \mathrm{l}$ ). Error bars represent $1 \mathrm{SEM}$, and asterisks indicate time points that differ from the corresponding baseline $(p<0.05)$. D-Phe, D-PheCRF ${ }_{12-41}$; INJ, intracerebroventricular injection.

in the lateral septum, as shown in Figure 2. In contrast, CRF decreased lateral septum 5-HT levels when administered after vehicle pretreatment, as shown previously (Fig. 1). D-PheCRF $\mathrm{P}_{12-41}$ did not significantly alter 5-HT levels when administered before the vehicle treatment. An overall two-way ANOVA indicated a significant effect of time $\left[F_{(11,275)}=1.95 ; p<0.05\right]$ and a significant group $\times$ time interaction $\left[F_{(22,275)}=2.10 ; p<0.01\right]$ but no significant effect of group $\left[F_{(2,25)}=1.65 ; \mathrm{NS}\right]$.

\section{Effects of intra-raphé administration of CRF on extracellular 5-HT levels}

Inf usion of CRF directly into the DRN decreased dialysate levels of 5-HT in both the lateral septum (Fig. 3) and the striatum (Fig. 4). Intra-raphé CRF ( 3 and $30 \mathrm{ng}$ ) produced a significant change of 5-HT levels in the lateral septum (Fig. $3 A$ ). An overall two-way ANOVA (0-120 min) demonstrated significant effects of dose $\left[F_{(2,17)}=3.72 ; p<0.05\right]$ and time $\left[F_{(9,153)}=2.02 ; p<0.05\right]$ but no significant interaction $\left[F_{(18,153)}=1.09\right.$; NS]. Extracellular 5-HT levels were significantly reduced from 10 to $60 \mathrm{~min}$ after injection at the $30 \mathrm{ng}$ dose. This decrease started within the first 10 min after injection and reached a nadir at $44 \pm 15 \%$ of baseline values $20 \mathrm{~min}$ after injection. Administration of $3 \mathrm{ng}$ of CRF decreased 5-HT levels to a nadir at $39 \pm 9 \%$ of baseline values $40 \mathrm{~min}$ after injection, whereas injection of vehicle into the dorsal raphé did not significantly alter lateral septum 5-HT levels (Fig. $3 A$ ). As seen in Figure $3 B$, CRF infusions outside of the DRN did not significantly affect lateral septum 5-HT levels $\left[F_{(3,84)}=1.29 ; \mathrm{NS}\right]$. Figure $3 C$ shows the location of infusions both within the DRN and in areas considered misses at a rostral level (left), intermediate level (middle), and caudal level (right) of 
Figure 3. Effects of intra-raphé CRF on extracellular 5-HT in the lateral septum. $A, B$, The $x$-axis indicates the time before and after intra-raphé infusion, which occurred at time $=0$. The $y$-axis indicates the extracellular 5-HT level per sample expressed as a percentage of the mean preinjection level. Error bars represent 1 SEM, and asterisks indicate time points that differ from the corresponding baseline $(p<0.05)$. A, The effects of intra-raphé vehicle (open circles; $n=8$; baseline 5-HT = $3.25 \pm 0.59 \mathrm{fmol} / 6.5 \mu \mathrm{l}$ ), $3 \mathrm{ng}$ of CRF (filled triangles; $n=5$; baseline $5-\mathrm{HT}=4.00 \pm 0.66 \mathrm{fmol} / 6.5 \mu \mathrm{l})$, or 30 ng of CRF (open squares; $n=8$; baseline $5-\mathrm{HT}=2.56 \pm$ $0.63 \mathrm{fmol} / 6.5 \mu \mathrm{l})$ are shown. $B$, The effects of CRF infusions outside of the DRN (filled circles; $n=4$; baseline 5 -HT $=3.46 \pm 1.09 \mathrm{fmol} / 6.5 \mu \mathrm{l})$ are shown. $C$, Location of infusion sites within and outside of the DRN from subjects administered 3 or $30 \mathrm{ng}$ of CRF is shown. The location of infusion sites was reconstructed onto plates 47, 49, and 51 (left to right) from Paxinos and Watson (1986); filled squares indicate infusion sites within the DRN, and open circles indicate inf usion sites outside of the DRN. $A q$, Cerebral aqueduct; $C G$, central gray; $C G D$, central gray, dorsal; $D R$, dorsal raphé nucleus; $m l f$, medial longitudinal fasciculus; $x s c p$, decussation of the superior cerebellar peduncle.
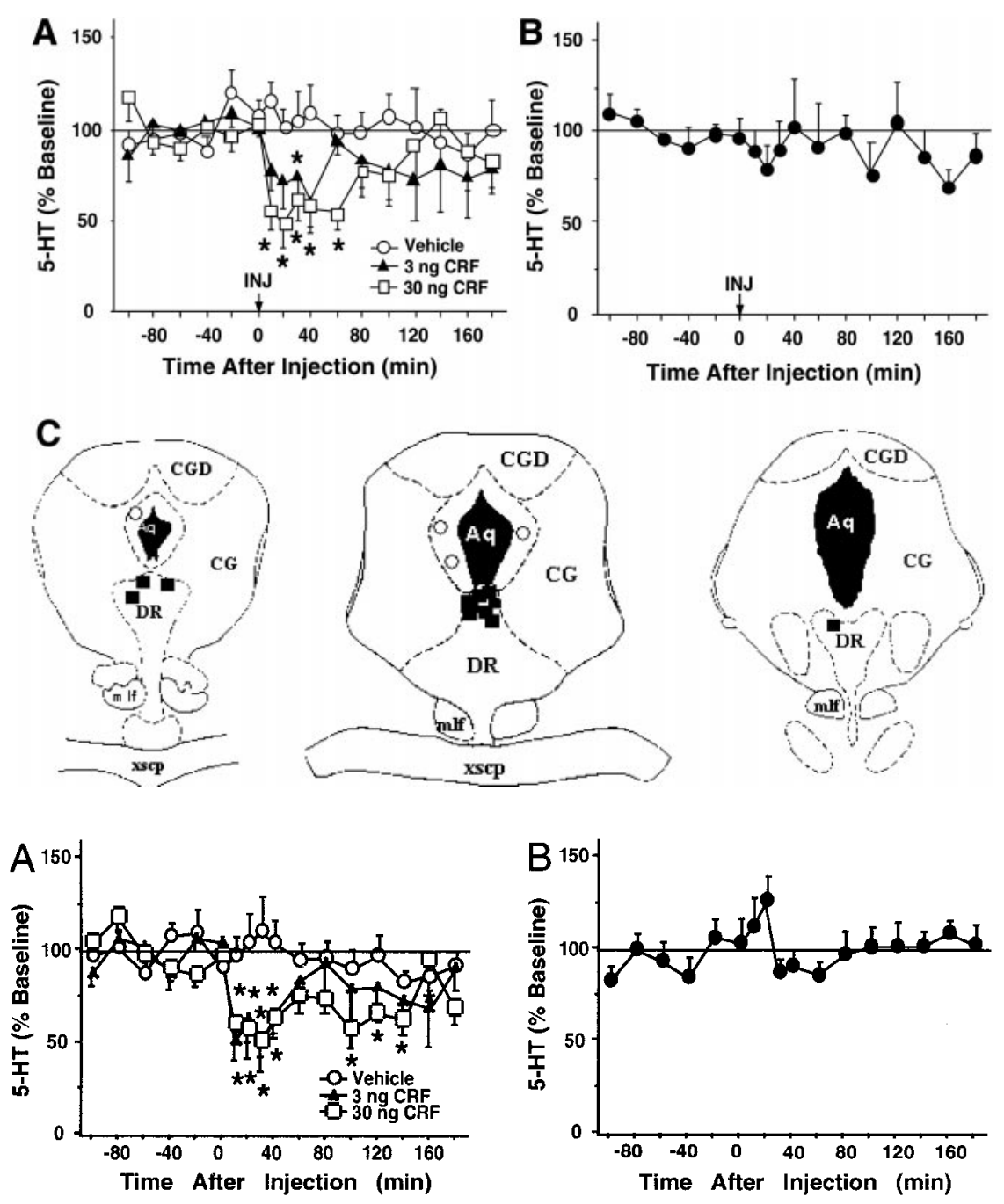

Figure 4. Effects of intra-raphé CRF on extracellular 5-HT in the striatum. $A$, $B$, The $x$-axis indicates the time before and after intra-raphé infusion, which occurred at time $=0$. The $y$-axis indicates the extracellular 5-HT level per sample expressed as a percentage of the mean preinjection level. Error bars represent $1 \mathrm{SEM}$, and asterisks indicate time points that differ from the corresponding baseline $(p<$ $0.05)$. $A$, The effects of intra-raphé vehicle (open circles; $n=6$; baseline $5-\mathrm{HT}=3.39 \pm 0.69 \mathrm{fmol} / 6.5$ $\mu \mathrm{l}$ ), $3 \mathrm{ng}$ of CRF ( filled triangles; $n=5$; baseline $5-\mathrm{HT}=3.24 \pm 0.19 \mathrm{fmol} / 6.5 \mu \mathrm{l})$, or $30 \mathrm{ng}$ of CRF (open squares; $n=5$; baseline 5 - $\mathrm{HT}=2.33 \pm 0.46$ fmol $/ 6.5 \mu \mathrm{l})$ are shown. $B$, The effects of CRF infusion outside of the raphé (filled circles; $n=8$; baseline $5-\mathrm{HT}=2.81 \pm 0.30 \mathrm{fmol} / 6.5 \mu \mathrm{l})$ are shown. $C$, Location of infusion sites within and outside of the DRN from subjects administered 3 or $30 \mathrm{ng}$ of CRF is shown. The location of infusion sites was reconstructed onto plates 47, 49, and 51 (left to right) from Paxinos and Watson (1986); filled squares indicate infusion sites within the DRN, and open circles indicate infusion sites outside of the DRN. See Figure 3 for abbreviations.
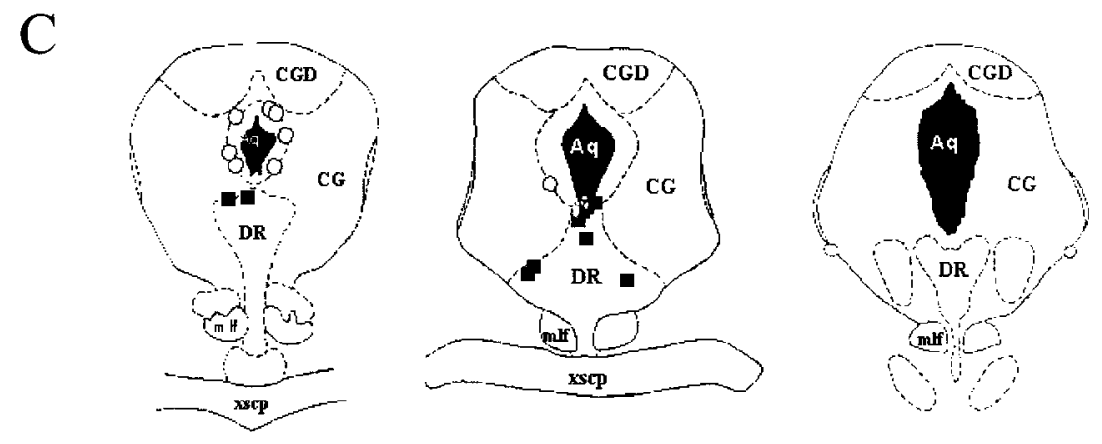

the DRN. Infusions within the DRN were localized to the dorsal portion of the nucleus, whereas misses were located around the cerebral aqueduct within the central gray.

In the striatum, intra-raphé CRF administration ( 3 and $30 \mathrm{ng}$ ) resulted in an overall significant change in 5-HT levels (0-120 min; Fig. 4A). An overall two-way ANOVA (0-120 min) demonstrated significant effects of dose $\left[F_{(2,12)}=4.28 ; p<0.05\right]$ and time $\left[F_{(8,96)}=2.10 ; p<0.05\right]$ but no significant interaction $\left[F_{(16,96)}=1.71 ; \mathrm{NS}\right]$. After the $30 \mathrm{ng}$ dose, 5 -HT levels were significantly reduced $10-40 \mathrm{~min}$ and again $100-140 \mathrm{~min}$ after injection. As in the lateral septum, this decrease began almost immediately after the injection and reached a nadir at $52 \pm 8 \%$ of baseline values $30 \mathrm{~min}$ after injection. Extracellular 5-HT levels were reduced to a nadir of $50 \pm 15 \%$ of baseline values 30 min after intra-raphé administration of $3 \mathrm{ng}$ of CRF, whereas infusion of vehicle did not significantly alter extracellular 5-HT levels in the striatum. Figure $4 B$ demonstrates that CRF infusions into areas outside of the DRN did not significantly affect extracellular 5-HT levels in the striatum $\left[F_{(8,64)}=1.37\right.$; NS]. Figure $4 C$ shows the location of inf usions both within the DRN and in areas considered misses at a rostral level (left), intermediate level (middle), and caudal level (right) of the DRN. The majority of infusions within the DRN were localized to the dorsal portion of the nucleus, whereas three infusions were made into the lateral 

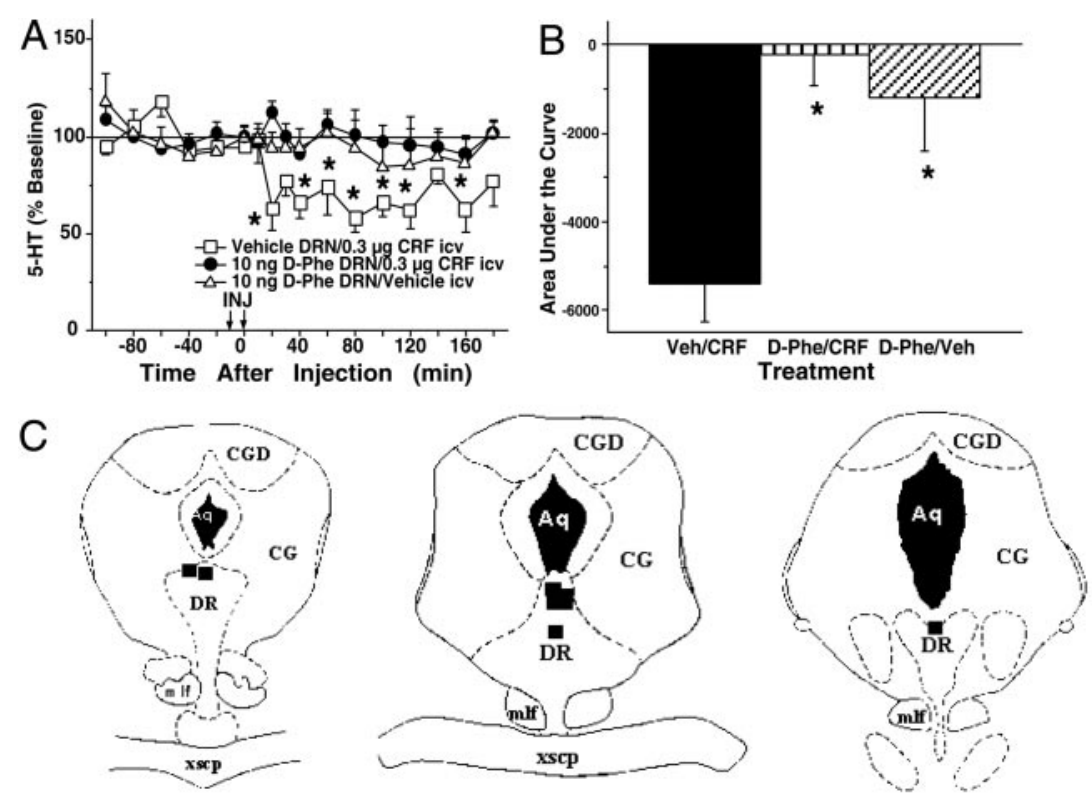

Figure 5. Effects of intracerebroventricular CRF after intra-raphé D-PheCRF ${ }_{12-41}$ on extracellular 5-HT levels in the lateral septum. $A$, The $x$-axis indicates the time before and after injections. Intra-raphé infusions occurred at time $=-9 \min$ (pretreatment), and intracerebroventricular infusions occurred at time $=0 \mathrm{~min}$ (treatment). The $y$-axis indicates the extracellular 5-HT level per sample expressed as a percentage of the mean preinjection level. The following effects are shown: vehicle pretreatment followed by CRF treatment (open squares; $n=6$; baseline 5 -HT $=$ $4.27 \pm 1.05 \mathrm{fmol} / 6.5 \mu \mathrm{l})$, D-PheCRF $\mathrm{C}_{12-41}$ pretreatment followed by CRF treatment (filled circles; $n=7$; baseline $5-\mathrm{HT}=3.82 \pm 0.51 \mathrm{fmol} / 6.5 \mu \mathrm{l})$, and $\mathrm{D}-\mathrm{PheCRF}_{12-41}$ pretreatment followed by vehicle treatment (open triangles; $n=5$; baseline 5 -HT $=3.81 \pm 0.64 \mathrm{fmol} / 6.5 \mu \mathrm{l})$. Error bars represent $1 \mathrm{SEM}$, and asterisks indicate time points that differ from the corresponding baseline $(p<0.05)$. $B$, The vertical bars indicate the mean effect of treatment on lateral septum 5-HT levels described by time and effect and expressed as the area under the curve. Asterisks indicate treatments that differed from vehicle pretreatment followed by CRF treatment $(p<0.05)$. $C$, Location of infusion sites within the DRN from subjects administered $10 \mathrm{ng}$ of DPheCRF $_{12-41}$ is shown. The location of infusion sites was reconstructed onto plates 47, 49, and 51 (left to right) from Paxinos and Watson (1986); filled squares indicate infusion sites within the DRN. See Figure 3 for abbreviations. Veh, Vehicle.

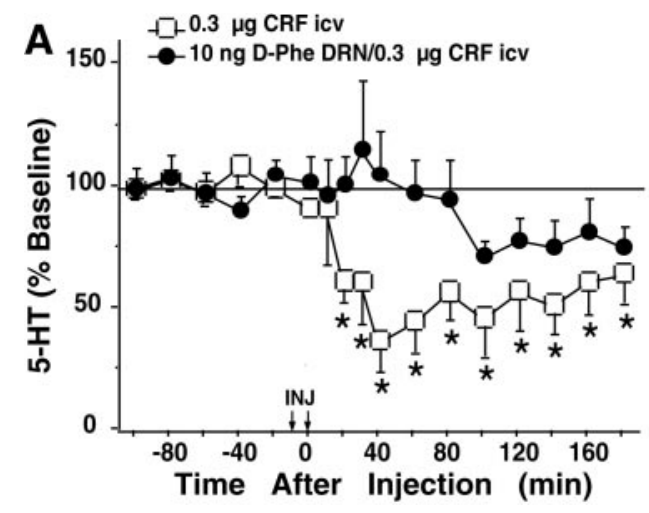

B
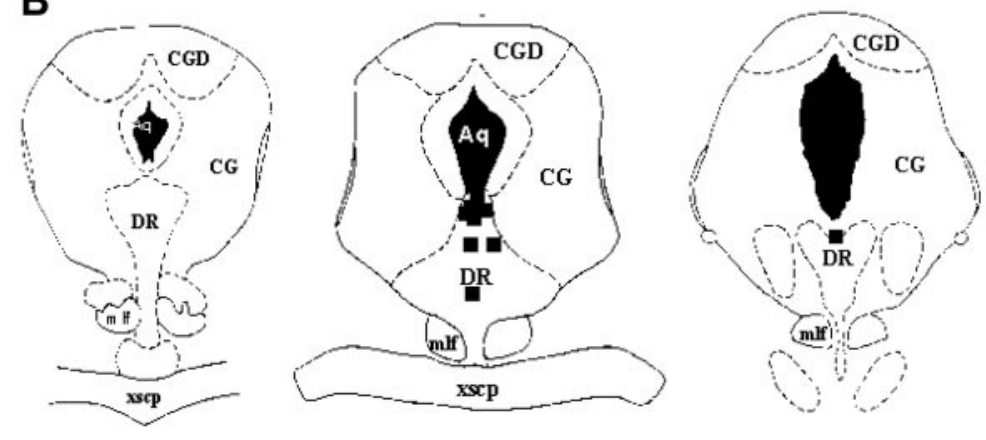

Figure 6. Effects of intracerebroventricular CRF after intra-raphé D-PheCRF ${ }_{12-41}$ on extracellular 5-HT levels in the striatum. $A$, The $x$-axis indicates the time before and after injections. Intra-raphé infusions occurred at time $=-9$ min (pretreatment), and intracerebroventricular infusions occurred at time $=0$ min (treatment). The $y$-axis indicates the extracellular 5-HT level per sample expressed as a percentage of the mean preinjection level. The following effects are shown: CRF treatment [open squares; $n=7$; baseline 5-HT $=6.23 \pm 0.81$ fmol/6.5 $\mu \mathrm{l}$; data from Price et al. (1998)] and D-PheCRF ${ }_{12-41}$ pretreatment followed by CRF treatment ( filled circles; $n=9$; baseline 5-HT $=3.40 \pm 0.54$ fmol/6.5 $\mu \mathrm{l}$ ). Error bars represent 1 SEM. Asterisks indicate time points that differ from the corresponding baseline $(p<0.05)$. B, Location of infusion sites within the DRN from subjects administered $10 \mathrm{ng}$ of D-PheCRF ${ }_{12-41}$ is shown. The location of infusion sites was reconstructed onto plates 47, 49, and 51 (left to right) from Paxinos and Watson (1986); filled squares indicate infusion sites within the DRN. See Figure 3 for abbreviations.

wings of the DRN. Inf usions outside of the DRN were made into the central gray adjacent to the cerebral aqueduct.

\section{Effects of intra-raphé administration of a CRF receptor antagonist on extracellular 5-HT levels}

Pretreatment with the CRF receptor antagonist D-PheCRF $\mathrm{F}_{12-41}$ (10 ng), but not vehicle, infused directly into the DRN significantly attenuated the effects of intracerebroventricular CRF administration $(0.3 \mu \mathrm{g})$ on extracellular levels of 5-HT in the lateral septum (Fig. $5 A$ ). An overall two-way ANOVA revealed a significant effect of treatment $\left[F_{(2,15)}=7.81 ; p<0.01\right]$ but no significant effect of time $\left[F_{(11,165)}=1.67\right.$; NS $]$ and no significant treatment $\times$ time interaction $\left[F_{(22,165)}=0.87 ; \mathrm{NS}\right]$. When administered before the vehicle treatment, D-PheCRF ${ }_{12-41}$ did not significantly alter 5-HT levels. In contrast, intracerebroventricular administration of CRF resulted in a reduction of lateral septum 5-HT levels when administered after vehicle pretreatment. Figure $5 B$ uses AUC values to summarize the attenuation of CRF-induced reductions in lateral septum 5-HT levels by pretreatment with intra-raphé D-PheCRF $\mathrm{P}_{12-41}$. AUC values for subjects that received pretreatment with $\mathrm{D}-\mathrm{PheCRF} \mathrm{F}_{12-41}$ followed by CRF treatment were significantly different from AUC values for subjects that received vehicle treatment followed by CRF treatment $\left[F_{(2,15)}=9.93 ; p<0.01\right]$. Figure $5 C$ illustrates the locations of D-PheCRF ${ }_{12-41}$ infusions within the DRN at a rostral level (left), intermediate level (middle), and caudal level (right) of the DRN. Infusions were localized to the dorsal and intrafasicular portions of the DRN.

As shown in Figure $6 A$, infusion of D-PheCRF ${ }_{12-41}(10 \mathrm{ng})$ into the DRN also blocked the effects of intracerebroventricular CRF treatment $(0.3 \mu \mathrm{g})$ on 5 -HT levels in the striatum $\left[F_{(8,11)}=\right.$ 

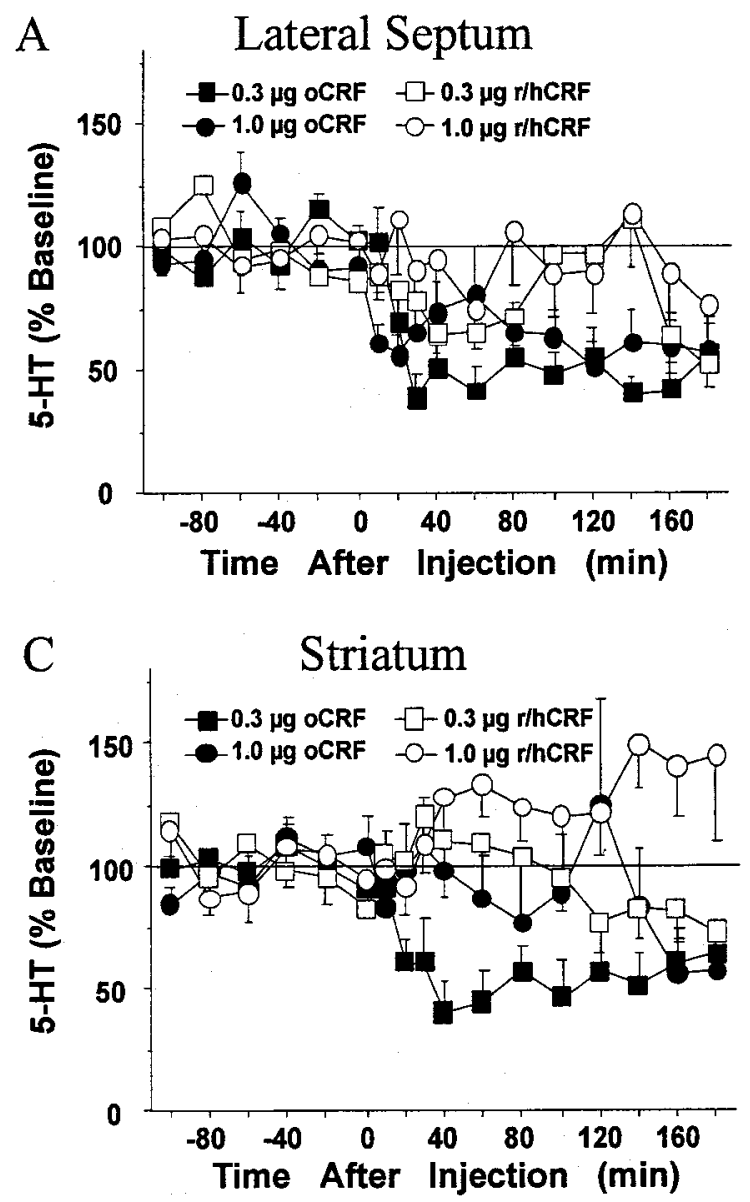

B

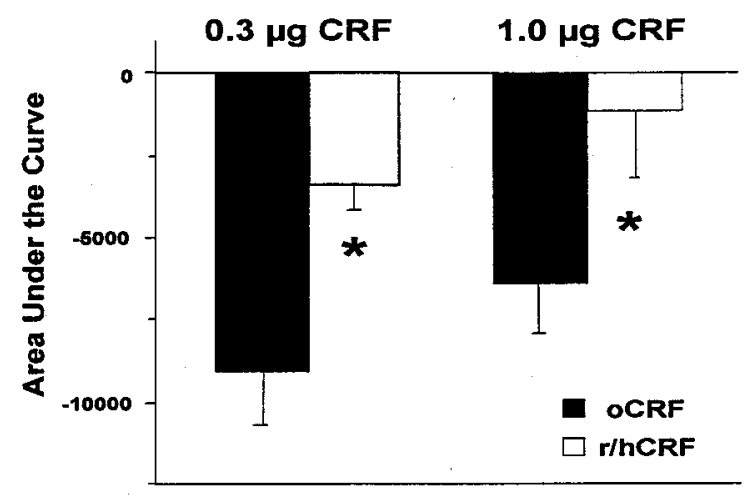

$\mathrm{D}$

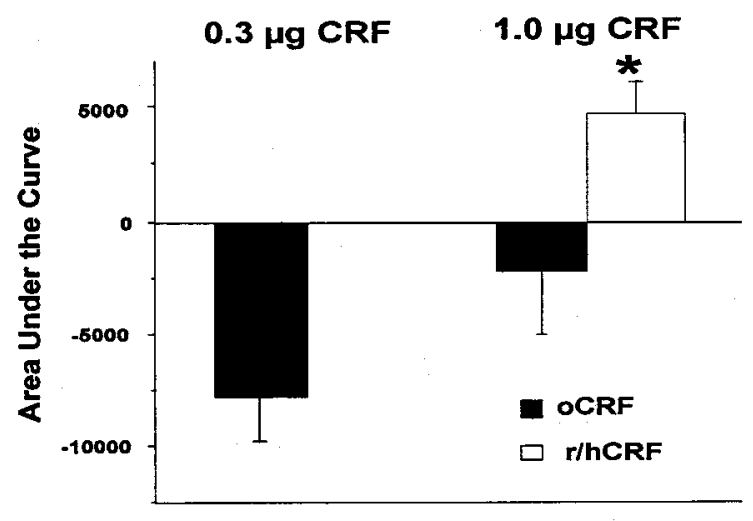

Figure 7. Comparison of effects of oCRF and $\mathrm{r} / \mathrm{hCRF}$ on extracellular levels of 5-HT in the lateral septum and the striatum. $A$, $C$, The $x$-axes indicate the time before and after intracerebroventricular injection, which occurred at time $=0$. The $y$-axes indicate the extracellular 5-HT level per sample expressed as a percentage of the mean preinjection level. Error bars represent $1 \mathrm{SEM}$. $A$. The effects of oCRF [0.3 $\mu \mathrm{g}$ ( filled squares; $n=6$; baseline $5-\mathrm{HT}=3.76 \pm 0.88 \mathrm{fmol} / 6.5 \mu \mathrm{l}$ ); $1.0 \mu \mathrm{g}$ ( filled circles; $n=7$; baseline 5 -HT $=3.58 \pm 1.02 \mathrm{fmol} / 6.5 \mu \mathrm{l})]$ and $\mathrm{r} / \mathrm{hCRF}[0.3 \mu \mathrm{g}$ (open squares; $n=5$; baseline 5 -HT $=2.58 \pm 0.35 \mathrm{fmol} / 6.5 \mu \mathrm{l}$ ); $1.0 \mu \mathrm{g}$ (open circles; $n=6$; baseline 5 -HT $=2.57 \pm 0.43 \mathrm{fmol} / 6.5 \mu \mathrm{l}$ ) on extracellular 5-HT levels in the lateral septum are compared. $C$, The effects of oCRF $[0.3 \mu \mathrm{g}$ ( filled squares; $n=7$; baseline 5 -HT $=6.23 \pm 0.81 \mathrm{fmol} / 6.5 \mu \mathrm{l}) ; 1.0 \mu \mathrm{g}$ ( filled circles; $n=6$; baseline $5-\mathrm{HT}=5.00 \pm 1.71 \mathrm{fmol} / 6.5 \mu \mathrm{l})$; data from Price et al. (1998) $]$ and $\mathrm{r} / \mathrm{hCRF}[0.3 \mu \mathrm{g}$ (open squares; $n=6$; baseline 5 -HT $=3.22 \pm 0.99 \mathrm{fmol} / 6.5 \mu \mathrm{l}$ ); 1.0 $\mu \mathrm{g}$ (open circles; $n=6$; baseline 5 -HT $=4.76 \pm 1.66 \mathrm{fmol} / 6.5 \mu \mathrm{l})]$ on extracellular 5 -HT levels in the striatum are compared. B, D, The vertical bars indicate the mean effect of oCRF and $\mathrm{r} / \mathrm{hCRF}$ on lateral septum $(B)$ or striatum $(D) 5$-HT levels described by time and effect and expressed as the area under the curve. Asterisks indicate differences between groups within each dose $(p<0.05)$.

1.54; NS]. Figure $6 B$ illustrates the locations of D-PheCRF $\mathrm{P}_{12-41}$ infusions within the DRN at a rostral level (left), intermediate level (middle), and caudal level (right). Inf usions were localized to the dorsal and intrafasicular regions of the DRN.

\section{Comparison of the effects of different forms of CRF on extracellular 5-HT levels}

As shown in Figure $7 A$, a significant decrease in lateral septum 5-HT was produced after intracerebroventricular treatment with 0.3 and $1.0 \mu \mathrm{g}$ of oCRF, whereas no significant alterations were seen after 0.3 or $1.0 \mu \mathrm{g}$ of $\mathrm{r} / \mathrm{hCRF}$ given intracerebroventricularly. An overall two-way ANOVA revealed significant effects of treatment $\left[F_{(3,20)}=4.21 ; p<0.05\right]$ and time $\left[F_{(11,220)}=2.48 ; p<\right.$ $0.01]$ but no significant interaction $\left[F_{(33,220)}=1.37\right.$; NS $]$ in the lateral septum. AUC values for subjects that received oCRF were significantly different from AUC values for subjects that received $\mathrm{r} / \mathrm{hCRF}$ at both the $0.3 \mu \mathrm{g}(p<0.05)$ and $1.0 \mu \mathrm{g}(p<0.05)$ doses, as demonstrated in Figure $7 B$.

A significant decrease of 5-HT in the striatum was produced after treatment with $0.3 \mu \mathrm{g}$ of oCRF, whereas no significant alterations were seen after 0.3 or $1.0 \mu \mathrm{g}$ of $\mathrm{r} / \mathrm{hCRF}$ as demonstrated in Figure $7 C$. In the striatum, an overall two-way ANOVA revealed significant effects of treatment $\left[F_{(3,21)}=5.25 ; p<0.01\right]$ and a significant interaction $\left[F_{(33,231)}=1.99 ; p<0.01\right]$ but no effect of time $\left[F_{(11,231)}=0.409 ;\right.$ NS $]$. As shown in Figure $7 D$, AUC values for subjects that received oCRF were significantly different from AUC values for subjects that received $\mathrm{r} / \mathrm{hCRF}$ at the $1.0 \mu \mathrm{g}(p<0.05)$ dose but not the $0.3 \mu \mathrm{g}$ dose.

\section{DISCUSSION}

\section{Regulation of extracellular 5-HT levels by CRF}

The localization of CRF innervation and CRF receptors to the DRN in rat (Swanson et al., 1983; Sakanaka et al., 1987; Potter et al., 1994; Chalmers et al., 1995; Kirby et al., 2000) and human (Ruggiero et al., 1999) brain has led to the speculation that CRF modulates the activity of the 5-HT system. Previous attempts to demonstrate effects of CRF on measures of 5-HT function using tissue content or turnover yielded variable results (Van Loon et al., 1982; Dunn and Berridge, 1987; Singh et al., 1991; Lavicky 
and Dunn, 1993). However, these studies used relatively indirect and unreliable measures of 5-HT activity. To provide a more direct measure of extracellular 5-HT that reflects neuronal activity, the present study used an in vivo microdialysis procedure sufficiently sensitive to measure reductions from baseline levels of 5-HT without the addition of a reuptake inhibitor in the perfusion fluid.

The present study quantified the effects of intracerebroventricular CRF on extracellular 5-HT levels in the lateral septum. A bimodal dose-response curve was measured, because only low doses of CRF (0.1-1.0 $\mu \mathrm{g})$ reduced extracellular 5-HT levels, an effect that was similar to the effects on striatal 5-HT produced by a similar treatment (Price et al., 1998). The common effect of CRF in the two different regions, both terminal regions of the DRN, implicates the DRN as the likely site of action. In contrast to the previous findings in the striatum where a higher dose of CRF increased 5-HT levels (Price et al., 1998), intracerebroventricular administration of a higher dose of CRF $(3.0 \mu \mathrm{g})$ did not increase 5-HT levels in the lateral septum. The excitatory effects of CRF in the striatum may result from its action on presynaptic heteroreceptors that may alter 5-HT levels indirectly via another neurotransmitter system.

The inhibitory effects of CRF on extracellular 5-HT levels in the lateral septum and the striatum agree with recent in vivo electrophysiological recordings of DRN neurons (Price et al., 1998; Kirby et al., 2000). These studies revealed predominantly inhibitory effects on DRN discharge rates after low doses of CRF, administered either intracerebroventricularly or intra-raphé. Also, a diminished effect was found at higher doses paralleling the pattern of the microdialysis results. Thus, in vivo microdialysis and in vivo electrophysiological studies support a functional interaction between CRF and DRN neuronal activity. In contrast, a study of CRF effects on DRN neurons in vitro reported excitatory effects on a small subpopulation $(27 \%)$ of neurons located in the ventral portion of the caudal DRN (Lowry et al., 2000). Differences between CRF effects in vitro and in vivo microdialysis and electrophysiology studies may be related to the region of the DRN studied; the study by Lowry et al. (2000) used tissue caudal to the region of the DRN examined in this study. Alternatively, the loss of inhibitory afferents in the slice preparation could also account for these differences.

Although some previous studies used $\mathrm{r} / \mathrm{hCRF}$ instead of oCRF, this study is one of the few that compared exogenous administration of oCRF with $\mathrm{r} / \mathrm{hCRF}$ directly by measuring the effects of intracerebroventricularly administered oCRF or $\mathrm{r} / \mathrm{hCRF}$ on 5-HT levels in the lateral septum and striatum. The two forms of CRF are $83 \%$ homologous (Eckart et al., 1999), but oCRF is more potent at CRF-R1 than at CRF-R2, whereas r/hCRF has a high affinity for both CRF-R1 and CRF-R2 (Sutton et al., 1985; DeSouza, 1987; Lovenberg et al., 1995; Primus et al., 1997). In addition, r/hCRF has a much higher binding affinity for the CRF-binding protein than does oCRF (Eckart et al., 1999). This study demonstrated a lack of efficacy of $\mathrm{r} / \mathrm{hCRF}$ on extracellular levels of 5-HT in the lateral septum or the striatum, consistent with the findings of Linthorst et al. (1997) in the hippocampus. Such findings could be attributed to relatively decreased bioavailability of $\mathrm{r} / \mathrm{hCRF}$ as a result of the activity of the CRF-binding protein. Alternatively, it is possible that CRF-R1 and CRF-R2 mediate neuronal inhibition and excitation, respectively. A recent electrophysiological study suggests that CRF-R1 is preferentially responsible for mediating the reduction in serotonergic neuronal firing after oCRF administration (Kirby et al., 2000). Recent ultrastructural data indicate that CRF-immunoreactive fibers form both symmetric (inhibitory-type) and asymmetric (excitatory-type) synapses in the DRN (Liouterman et al., 1999). Because r/hCRF, but not oCRF, has a high affinity for both CRF receptor subtypes, the net result of $\mathrm{r} / \mathrm{hCRF}$ on extracellular 5-HT levels in the terminal regions examined may be cancelled out.

\section{Localization of the effects of CRF to the DRN}

This study demonstrates that an important site of CRF regulation of 5-HT transmission can be localized to 5-HT-containing cells in the DRN. Inf usion of CRF directly into the DRN, at doses 10- to 100 -fold lower than the effective intracerebroventricular doses, produced similar reductions in extracellular 5-HT in both the lateral septum and striatum. Internal controls suggest that the decreases in extracellular 5-HT were caused by an effect of CRF within the DRN because injections outside of the DRN had no effect on 5-HT levels although the infusion sites were adjacent to the cerebral aqueduct and cannulae for some of the infusions were placed such that they actually penetrated the cerebral aqueduct. In addition, the lowest dose of CRF given intracerebroventricularly in this study $(0.1 \mu \mathrm{g})$ had no effect on extracellular 5-HT levels in the lateral septum although it is over threefold greater than the largest dose of CRF inf used into the DRN (30 ng).

The CRF-induced decrease of extracellular 5-HT levels in the lateral septum was blocked by pretreatment with D-PheCRF $\mathrm{P}_{12-41}$, a CRF receptor antagonist with high affinity for both CRF-R1 and CRF-R2. The ability of intra-raphé administration of D-PheCRF ${ }_{12-41}$ to block the effects of intracerebroventricular CRF confirmed that the effects of CRF on extracellular 5-HT in the lateral septum and striatum are caused by interactions within the DRN. Although CRF-containing neurons densely innervate the DRN (Kirby et al., 2000; Lowry et al., 2000), it is not clear whether CRF receptors are directly on 5-HT neurons or act indirectly by altering the activity of afferent neurons. Neurotoxininduced selective lesions of 5-HT neurons diminish a significant portion of CRF-binding sites in the DRN, supporting possible direct and indirect modulation of 5-HT transmission by CRF in the DRN (R. J. Valentino, personal communication).

\section{CRF and the effects of stress on extracellular 5-HT levels}

The lateral septum is associated with emotional expression of fear and anxiety (Thomas, 1988), the striatum is associated with movement and some aspects of cognition (Afifi, 1994), and both regions receive prominent 5-HT innervation from the DRN (Jacobs and Azmitia, 1992). Taken together with reports of CRF receptors and immunoreactive fibers in the DRN (Swanson et al., 1983; Sakanaka et al., 1987; Chalmers et al., 1995; Kirby et al., 2000) and inhibitory effects of CRF on 5-HT neuronal firing (Price et al., 1998; Kirby et al., 2000), the present findings support the hypothesis that CRF acts as a neurotransmitter in the DRN to regulate the release of 5-HT in the striatum and lateral septum (Jacobs and Azmitia, 1992) and probably other forebrain regions. Functionally, CRF mechanisms within the DRN may mediate the effects of stress on the 5-HT system (Chaouloff, 1993). Several physiological conditions have been shown to both decrease extracellular 5-HT levels in specific forebrain regions and elicit increases in CRF levels, including acute withdrawal from chronic cocaine administration (Parsons et al., 1995; Sarnyai et al., 1995), withdrawal from chronic ethanol administration (Menzaghi et al., 1994; Weiss et al., 1996), and acute administration of insulin (Plotsky, 1985; Orosco and Nicolaidis, 1994). Forced-swimming 
stress, which produces behavioral dysfunctions that are sensitive to antidepressant drugs (Borsini and Meli, 1988), has also been reported to reduce extracellular 5-HT levels in the DRN, amygdala, and lateral septum (Chou et al., 1995; Kirby et al., 1995), although the effects of this stressor on CRF levels have not been reported. However, pretreatment with the CRF receptor antagonist $\mathrm{D}-\mathrm{PheCRF}_{12-41}$ prevented the reduction of extracellular 5-HT levels in the lateral septum caused by forced swimming (Price and Lucki, 2000), suggesting the involvement of CRF in mediating the effects of this stressor on 5-HT transmission. Taken together with reports that CRF is hypersecreted in depressed patients or in suicide victims (Nemeroff et al., 1984; Banki et al., 1987), with reports of reduced numbers of CRF receptors in the brains of suicide victims (Nemeroff et al., 1988), and with more recent studies demonstrating antidepressant-like effects of CRF receptor antagonists (Mansbach et al., 1997), it is justified to speculate that CRF regulation of the 5-HT system may be important in mediating the 5-HT alterations seen in several neuropsychiatric disorders, such as depression and anxiety (Maes and Meltzer, 1995).

\section{REFERENCES}

Afifi A (1994) Basal ganglia: functional anatomy and physiology. J Child Neurol 9:352-361

Banki CM, Bissette G, Arato M, O'Connor L, Nemeroff CB (1987) CSF corticotropin-releasing factor-like immunoreactivity in depression and schizophrenia. Am J Psychiatry 144:873-877.

Borsini F, Meli A (1988) Is the forced swimming test a suitable model for revealing antidepressant activity? Psychopharmacology (Berl) 94: 147-160.

Butler PD, Weiss JM, Stout JC, Nemeroff CB (1990) Corticotropinreleasing factor produces fear-enhancing behavioral activating effects following infusion into the locus coeruleus. J Neurosci 10:176-183.

Chalmers DT, Lovenberg TW, DeSouza EB (1995) Localization of novel corticotropin-releasing factor receptor (CRF2) mRNA expression to specific subcortical nuclei in rat brain: comparison with CRF1 receptor mRNA expression. J Neurosci 15:6340-6350.

Chaouloff F (1993) Physiopharmacological interactions between stress hormones and central serotonergic systems. Brain Res Rev 18:1-32.

Chou JM, Kirby LG, Lucki I (1995) Effect of forced swimming stress on extracellular levels of 5-HT in the dorsal raphe nucleus of the rat. Soc Neurosci Abstr 21:2058.

Cummings S, Elde R, Ells J, Lindall A (1983) Corticotropin-releasing factor immunoreactivity is widely distributed within the central nervous system on the rat: an immunohistochemical study. J Neurosci 3:1355-1368

Curtis AL, Grigoriadis D, Page ME, Rivier J, Valentino RJ (1994) Pharmacological comparison of two corticotropin-releasing factor antagonists: in vivo and in vitro studies. J Pharmacol Exp Ther 268:359-365

Curtis AL, Florin-Lechner SM, Pavcovich LA, Valentino RJ (1997) Activation of the locus coeruleus noradrenergic system by intracoerulear microinfusion of corticotropin-releasing factor: effects on discharge rate, cortical norepinephrine levels and cortical electroencephalographic activity. J Pharmacol Exp Ther 281:163-172.

DeSouza EB (1987) Corticotropin-releasing factor receptors in the rat central nervous system: characterization and regional distribution. J Neurosci 7:88-100.

Dunn AJ, Berridge CW (1987) Corticotropin-releasing factor administration elicits a stress-like activation of cerebral catecholaminergic systems. Pharmacol Biochem Behav 27:685-691.

Dunn AJ, Berridge CW (1990) Physiological and behavioral responses to corticotropin-releasing factor administration: is CRF a mediator of anxiety or stress responses? Brain Res Rev 15:71-100.

Eckart K, Radulovic J, Radulovic M, Jahn O, Blank T, Stiedl O, Spiess J (1999) Actions of CRF and its analogs. Curr Med Chem 6:1035-1053.

Jacobs BL, Azmitia EC (1992) Structure and function of the brain serotonin system. Physiol Rev 72:165-229.

Kirby LG, Allen AR, Lucki I (1995) Regional differences in the effects of forced swimming on extracellular levels of 5-hydroxytryptamine and 5-hydroxyindoleacetic acid. Brain Res 682:189-196.

Kirby LG, Chou-Green JM, Davis K, Lucki I (1997) The effects of different stressors on extracellular 5-hydroxytryptamine and 5-hydroxyindoleacetic acid. Brain Res 760:218-230.

Kirby LG, Rice KG, Valentino RJ (2000) Effects of corticotropinreleasing factor on neuronal activity in the serotonergic dorsal raphe nucleus. Neuropsychopharmacology 22:148-161.
Kreiss DS, Wieland S, Lucki I (1993) The presence of a serotonin uptake inhibitor alters pharmacological manipulations of serotonin release. Neuroscience 52:295-301.

Lavicky J, Dunn AJ (1993) Corticotropin-releasing factor stimulates catecholamine release in hypothalamus and prefrontal cortex in freely moving rats as assessed by microdialysis. J Neurochem 60:602-612.

Lechner SM, Curtis AL, Brons R, Valentino RF (1997) Locus coeruleus activation by colon distension: role of corticotropin-releasing factor and excitatory amino acids. Brain Res 756:114-124.

Linthorst ACE, Flachskamm C, Hopkins SJ, Hoadley ME, Labeur MS, Holsboer F, Reul JMHM (1997) Long-term intracerebroventricular infusion of corticotropin-releasing hormone alters neuroendocrine, neurochemical, autonomic, behavioral, and cytokine responses to a systemic inflammatory challenge. J Neurosci 17:4448-4460.

Liouterman L, Van Bockstaele EJ, Valentino RJ (1999) Heterogeneous distribution of corticotropin releasing factor (CRF) in the serotonergic dorsal raphe nucleus (DRN). Soc Neurosci Abstr 25:2221.

Lovenberg TW, Liaw CW, Grigoriadis DE, Clevenger W, Chalmers DT, DeSouza EB, Oltersdorf T (1995) Cloning and characterization of a functionally distinct corticotropin-releasing factor subtype from rat brain. Proc Natl Acad Sci USA 92:836-840.

Lowry CA, Rodda JE, Lightman SL, Ingram CD (2000) Corticotropinreleasing factor increases in vitro firing rates of serotonergic neurons in the rat dorsal raphe nucleus: evidence for activation of a topographically organized mesolimbocortical serotonergic system. J Neurosci 20:7728-7736.

Maes M, Meltzer HY (1995) The serotonin hypothesis of major depression. In: Psychopharmacology: the fourth generation of progress (Bloom FE, Kupfer DJ, eds), pp 933-944. New York: Raven.

Mansbach RS, Brooks EN, Chen YL (1997) Antidepressant-like effects of CP-154,526, a selective CRF1 receptor antagonist. Eur J Pharmacol 323:21-26.

Matsuzaki I, Takamatsu Y, Moroji T (1989) The effects of intracerebroventricularly injected corticotropin-releasing factor (CRF) on the central nervous system: behavioral and biochemical studies. Neuropeptides 13:147-155.

Menzaghi F, Rassnick S, Heinrichs S, Baldwin H, Pich EM, Weiss F, Koob GF (1994) The role of corticotropin-releasing factor in the anxiogenic effects of ethanol withdrawal. Ann NY Acad Sci 739:176-184.

Nemeroff CB, Widerlov E, Bissette GT, Walleus H, Karlson I, Eklund K, Kilts C, Loosen P, Vale W (1984) Elevated concentrations of CSF corticotropin-releasing factor-like immunoreactivity in depressed patients. Science 226:1342-1344.

Nemeroff CB, Owens MJ, Bissette GT, Andorn AC, Stanley M (1988) Reduced corticotropin-releasing factor (CRF) binding sites in frontal cortex of suicide patients. Arch Gen Psychiatry 45:577-579.

Orosco M, Nicolaidis S (1994) Insulin and glucose-induced changes in feeding and medial hypothalamic monoamines revealed by microdialysis in rats. Brain Res Bull 33:289-297.

Owens MJ, Nemeroff CB (1991) Physiology and pharmacology of corticotropin-releasing factor. Pharmacol Rev 43:425-474.

Page M, Abercrombie E (1999) Discrete local application of corticotropin-releasing factor increases locus coeruleus discharge and extracellular norepinephrine in rat hippocampus. Synapse 33:304-313.

Parsons LH, Koob GF, Weiss F (1995) Serotonin dysfunction in the nucleus accumbens of rats during withdrawal after unlimited access to intravenous cocaine. J Pharmacol Exp Ther 274:1182-1191.

Paxinos G, Watson C (1986) The rat brain in stereotaxic coordinates. San Diego: Academic.

Plotsky PM (1985) Hypophysiotropic regulation of adenohypophyseal adrenocorticotropin secretion. Fed Proc 344:207-214.

Potter E, Sutton S, Donaldson C, Chen R, Perrin M, Lewis K, Sawchenko PE, Vale W (1994) Distribution of corticotropin-releasing factor receptor mRNA expression in the rat brain and pituitary. Proc Natl Acad Sci USA 91:8777-8781.

Price ML, Lucki I (2000) Administration of the corticotropin-releasing factor (CRF) receptor antagonist D-PheCRF-(12-41) alters serotonin (5-HT) release in the lateral septum during forced swimming. Soc Neurosci Abstr 26:402.

Price ML, Curtis AL, Kirby LG, Valentino RJ, Lucki I (1998) Effects of corticotropin-releasing factor on brain serotonergic activity. Neuropsychopharmacology 18:492-502.

Primus RJ, Yevich E, Baltazar C, Gallager DW (1997) Autoradiographic localization of $\mathrm{CRF}_{1}$ and $\mathrm{CRF}_{2}$ binding sites in adult rat brain. Neuropsychopharmacology 17:308-316.

Ruggiero DA, Underwood MD, Rice PM, Mann JJ, Arango V (1999) Corticotropic-releasing hormone and serotonin interact in the human brainstem: behavioral implications. Neuroscience 91:1343-1354.

Sakanaka M, Shibasaki T, Lederes K (1987) Corticotropin-releasing factor-like immunoreactivity in the rat brain as revealed by a modified cobalt-glucose oxide-diaminobenzidine method. J Comp Neurol 260:256-298.

Sarnyai Z, Biro E, Gardi J, Vecsernyes M, Julesz J, Telegdy G (1995) Brain corticotropin-releasing factor mediates "anxiety-like" behavior induced by cocaine withdrawal in rats. Brain Res 675:89-97. 
Singh VB, Hao-Phan T, Corley KC, Boadle-Biber MC (1991) Increase in cortical and midbrain tryptophan hydroxylase activity by intracerebroventricular administration of corticotropin-releasing factor: block by adrenalectomy, by RU 38486 and by bilateral lesions to the central nucleus of the amygdala. Neurochem Int 20:81-92.

Sutton SW, Behan DP, Lahrichi SL, Kaiser R, Corrigan A, Lowry P, Potter E, Perrin MH, Rivier J, Vale W (1985) Ligand requirements of the human corticotropin releasing factor-binding protein. Endocrinology 136:1097-1102.

Swanson LW, Sawchenko PE, Rivier J, Vale W (1983) Organization of ovine corticotropin-releasing factor immunoreactive cells and fibers in rat brain: an immunohistochemical study. Neuroendocrinology 36:165-186.

Thomas E (1988) Forebrain mechanisms in the relief of fear: the role of the lateral septum. Psychobiology 16:36-44.

Vale W, Spiess J, Rivier C, Rivier J (1981) Characterization of a 41residue ovine hypothalamic peptide that stimulates secretion of corticotropin and beta-endorphin. Science 213:1394-1397.
Valentino RJ, Foote SL, Aston-Jones G (1983) Corticotropin-releasing factor activates noradrenergic neurons of the locus coeruleus. Brain Res 270:363-367.

Valentino RJ, Page ME, Curtis AL (1991) Activation of noradrenergic locus coeruleus neurons by hemodynamic stress is due to local release of corticotropin-releasing factor. Brain Res 555:25-34.

Valentino RJ, Foote SL, Page ME (1993) The locus coeruleus as a site for integrating corticotropin-releasing factor and noradrenergic mediation of stress responses. Ann NY Acad Sci 697:173-188.

Van Loon GR, Shum A, Ho D (1982) Lack of effect of corticotropinreleasing factor on hypothalamic dopamine and serotonin synthesis turnover rates in rats. Peptides 3:799-803.

Weiss F, Parsons LH, Schulteis G, Hyytia P, Lorang MT, Bloom FE, Koob GF (1996) Ethanol self-administration restores withdrawalassociated deficiencies in accumbal dopamine and 5-hydroxytryptamine release in dependent rats. J Neurosci 16:3474-3485. 